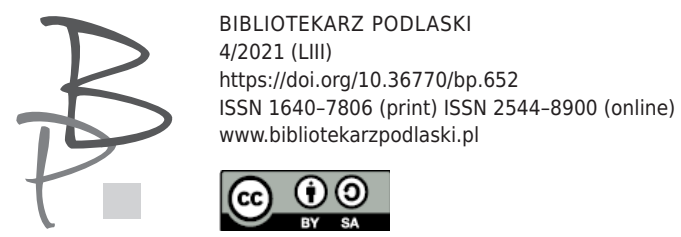

Iwona E. Rusek*

Uniwersytet w Białymstoku, Polska / University of Białystok, Poland

ORCID: 0000-0002-4894-7987

\title{
„Jedz, laleczko...", czyli o zaświatowym charakterze niektórych potraw
}

\author{
"Eat, dolly...", about the role of certain foods in afterlife
}

\begin{abstract}
The article describes the ritual function of the funeral ritual of feeding the ancestors and the foods associated with it, such as bread, cake, fruit, honey, milk, alcohol, and lentils. On the example of Adam Mickiewicz's Dziady [Forefathers' Eve], the author shows the sense and meaning of the food of the dead and the act of "feeding" the spirits. On the other hand, the use of fairy tales is intended to extract additional information about the foods (raspberries, blueberries, strawberries, cabbage, meat) and their role in the text.
\end{abstract}

Keywords: death, funeral, ritual, wake, fairy tale, foods for the dead.

Od wieków życie człowieka podzielone było na trzy najważniejsze momenty: narodziny, wesele oraz śmierć. Każdemu z tych etapów towarzyszyły obrzędy, a ich symbolika wpisywała się w rytm otaczającej przyrody.

Rytuały pogrzebowe związane z procesem umierania oraz samą śmiercią zawierały bogatą sferę ceremonii, w których istotną rolę odgrywał pokarm.

* Iwona Elżbieta Rusek - dr hab., adiunkt na Wydziale Filologicznym Uniwersytetu w Białymstoku, pracuje w Zakładzie Badań Źródłowych nad Literaturą XIX i XX wieku, autorka m.in. monografii Życia lampy niewygaste. Studium o „Oziminie” Wacława Berenta (2017). 
Był on stosowany do karmienia zmarłych tuż po zgonie, wkładany im do grobu lub pozostawiany na mogile. Zazwyczaj obok łoża zmarłego ustawiano naczynie z wodą (która miała znaczenie oczyszczające), kieliszek wódki, chleb z masłem, mięso, sery, a niekiedy piwo' ${ }^{1}$. Obecność pokarmu doprowadziła do powstania uczty pogrzebowej. Brali w niej udział wszyscy żałobnicy, znajomi oraz sam nieboszczyk, dla którego ustawiano przy progu krzesło z kieliszkiem wódki i kromką chleba, niekiedy zapraszano zmarłego do stołu, zostawiając dla niego miejsce między biesiadującymi².

Stypa była jednym z najważniejszych elementów rytuału pogrzebowego, ponieważ zapewniała zmarłemu przepełnione szacunkiem odejście, a także pamięć u potomków i krewnych. Podczas stypy podawano więc pokarmy, które jednoczyły żywych ze zmarłymi, zaś tym ostatnim pozwalały uzyskać wieczny spokój duszy. Do serwowanych w trakcie uczty potraw zaliczamy kutię z maku i pszenicy utartą z miodem, pieczone na tę okazję chleby i pierogi oraz bób, groch, soczewicę ${ }^{3}$ a także mak, mięso, kapustę, chleb z masłem, ser, kaszę i ryby ${ }^{4}$. Pito zazwyczaj alkohol, który jako mediator w zaświaty dopełniał obrzędowy charakter funeralnej biesiady.

Z rytuału pogrzebowego, jakim było karmienie zmarłych, powstał zwyczaj, a następnie obrzęd przygotowywania jedzenia oraz napojów na Święto Bożego Narodzenia oraz Święto Zmarłych. Potrawy takie, jak chleb, kutia, kasza, pierogi, miód, spożywane w trakcie Wigilii służyły jako ochrona przed demonami ${ }^{5}$, pełniły także funkcję ofiary-mediatora w kontaktach z zaświatami. Nieprzypadkowo więc pusty talerz przeznaczony był dla zmarłych przodków, dziadów właśnie, których zapraszano do wspólnej biesiady w ten wieczór.

Najsłynniejszą ilustrację obrzędu karmienia przodków znajdujemy w części II Dziadów Adama Mickiewicza, który we wstępie pisał:

1 A. Fischer, Zwyczaje pogrzebowe ludu polskiego, Lwów 1921, s. 195, 196.

2 H. Biegeleisen, Śmierć w obrzędach i zwyczajach ludu polskiego, Sandomierz 2017, s. $259,260$.

3 B. Ogrodowska, Polskie zwyczaje i obrzędy doroczne, Warszawa 2012, s. 237.

4 A. Fischer, dz. cyt., s. 377, 378, 379.

5 J. Wawrzeniuk, Jak wygladały stowiańskie „,mosty” w zaświaty? - Spojrzenie archeologiczne, [w:] Za miedze, za morze, w zaświaty... Kulturowe wymiary podróżowania, red. W. Olszewski, V. Wróblewska, Wrocław 2012, s. 254-255. 
[...] pospólstwo więc święci Dzi a dy tajemnie w kaplicach lub pustych domach niedaleko cmentarza. Zastawia się tam pospolicie uczta z rozmaitego jadła, trunków, owoców i wywołują się dusze nieboszczyków. Godna uwagi, iż zwyczaj częstowania zmarłych zdaje się być wspólny wszystkim ludom pogańskim, w dawnej Grecji za czasów homerycznych, w Skandynawii, na Wschodzie i dotąd po wyspach Nowego Świata. Dzia dy nasze mają to szczególnie, iż obrzędy pogańskie pomieszane są z wyobrażeniami religii chrześcijańskiej, zwłaszcza iż dzień zaduszny przypada około czasu tej uroczystości. Pospólstwo rozumie, iż potrawami, napojem i śpiewami przynosi ulgę duszom czyśćcowym6.

Wedle słów Guślarza w kaplicy znajduje się specjalnie przygotowane na tę okazję jadło oraz napoje. Toteż gdy pojawiają się mary dzieci, Kapłan zachęca je, by posiliły się:

\section{Czego potrzebujesz, duszeczko,}

Żeby się dostać do nieba?

Czy prosisz o chwałę Boga?

Czyli o przysmaczek słodki?

Są tu pączki, ciasta, mleczko

I owoce, i jagódki.

Czego potrzebujesz, duszeczko,

Żeby się dostać do nieba?

$$
\text { (w. 83-90). }
$$

Pączki i ciasta, które wskazuje Guślarz, zaliczyć możemy do pieczywa obrzędowego, które w formie chlebów/chlebków wypiekano w piecu, podobnie jak skwarodniki, czyli ciasto drożdżowe pieczone na patelni lub także w piecu? Chleb, który stanowi połączenie wody i zboża, pod wpływem ognia z bezkształtnej masy transformuje się w bochenki, co sprawia, że pełni funkcję pokarmu istot zaświatowych oraz, co istotne, uczestniczy we wszystkich

6 A. Mickiewicz, Dziady, Warszawa 1995, s. 11. Wszystkie cytaty pochodzą z tego wydania. W nawiasach będę podawała numery wersów.

7 G. Charytoniuk-Michiej, Obrzęd Dziadów w dokumentach $i$ w cyklu Mickiewicza, Warszawa 2011, s. 198. 
rytuałach obrzędowych (święcenie chleba na Wielkanoc, łamanie się opłatkiem przy Wigilijnym stole, przyjmowanie Komunii podczas mszy świętej ${ }^{8}$ ). Piec, w którym pieczono chleby, ciasta, a nawet pierogi ${ }^{9}$, stanowił symboliczne odwzorowanie kobiecego łona i dlatego był miejscem o właściwościach magicznych oraz mediacyjnych, zwłaszcza z zaświatami ${ }^{10}$. Mleko od wieków stanowiło pokarm istot demonicznych, w tym węży, symbolizowało także odrodzenie oraz nieśmiertelnośćl ${ }^{11}$ z kolei owoce były siedzibą duszy, wskazywały również na ludzkie cnoty i grzechy ${ }^{12}$.

Jednak duchy dzieci nie chcą ani „modłów”, ani żadnego jadła z tak obficie przygotowanej biesiady. Proszą natomiast o „gorczycy dwa ziarna”, bowiem z punktu widzenia symbolicznego i rytualnego ziarenka były prawdziwym pokarmem dla ducha i oznaczały oczyszczenie ${ }^{13}$. Z kolei liczba dwa jako parzysta przynależna była Tamtej Stronie i dlatego kojarzono ją, podobnie jak inne parzyste liczby, ze śmiercią (stąd zwyczaj bukietów lub wieńców pogrzebowych o takiej właśnie liczbie kwiatów).

Przybyły do kaplicy duch złego pana żali się: „Wiecznych głodów jestem pastwą;/ A któż mię nakarmić raczy?” (w. 196-197), na co Guślarz proponuje mu „chleb, mleko”, a także, jak w przypadku duchów dziecięcych, owoce oraz jagody. Jednak zły pan wie, że zgodnie z karą, którą musi odbywać od wschodu do zachodu i od zachodu do wschodu słońca, nie dane mu będzie zaspokoić ani głodu, ani pragnienia. Cierpienie, jakie w związku z tym odczuwa, jest tak wielkie, że zwraca się do zebranych z żałośliwą prośbą: „Ach, jak mnie pragnienie pali; Gdyby mała wody miarka!/ Ach! gdybyście mnie podali/ Choćby dwa pszenicy ziarka!" (w. 232-235). Woda, o którą prosi Widmo, nie służy tylko do zaspokojenia pragnienia, lecz także oczyszczenia duchowego, zaś pszenica była składnikiem między innymi kutii, czyli obrzędowej potrawy,

8 P. Kowalski, Kultura magiczna. Omen, przesąd, znacznie, Warszawa 2007, s. 440.

9 Guślarz wymienia pierogi w chwili, gdy pojawia się milczące Widmo. Jednak duch ten ani nie chce wyznać swej winy, ani wskazać potrawy, którą miałby zostać nakarmiony.

10 Tamże, s. 438.

11 J. Tresidder, Stownik symboli, przeł. B. Stokłosa, Warszawa 2005, s. 132.

12 Leksykon symboli. Herder, przeł. J. Prokopiuk, Warszawa 2009, s. 210; Á. P. Chenel, A. S. Simarro, Słownik symboli, przeł. M. Boberska, Warszawa 2008, s. 174.

13 W. Kopaliński, Stownik symboli, Warszawa 1990, s. 230. 
którą karmiono zmarłych. Gdyby pan mógł skosztować choćby tych dwóch ziarenek, rytuał zostałby dopełniony, a jego dusza mogłaby zaznać spokoju. Tak się niestety nie dzieje i Widmo odchodzi na wieczną mękę.

Pod koniec dramatu z ust Guślarza daje się słyszeć wezwanie:

Teraz wszystkie dusze razem,

Wszystkie i każdą z osobna,

Ostatnim wołam rozkazem!

Dla was ta biesiada drobna;

Garście maku, soczewicy

Rzucam w każdy róg kaplicy.

(w. 504-510).

Mak i soczewica są potrawami żałobnymi, związanymi ze śmiercią, a róg pokoju, podobnie jak miejsce za obrazem, to przestrzenie, w których bytują duchy. Tam więc Guślarz składa ofiarę z jadła, by nakarmić nią wszystkich nieujawnionych dotąd uczestników biesiady. Ale gest Guślarza posiada jeszcze jedno ważne znaczenie, mianowicie kiedy mówi: „rzucam”, nie chodzi mu tylko o fizyczny akt, jakim jest rzucenie pokarmów, ale o coś jeszcze. To zaś związane jest z duchem pośrednim, czyli dziewicą, która na pytanie Kapłana: „,czego potrzebujesz, duszeczko,/ Żeby się dostać do nieba?”, bez wahania mówi:

„[...]

Niechaj podbiegną młodzieńce,

Niechaj mię pochwycą za ręce,

Niechaj przyciągną do ziemi,

Niech poigram chwilkę z niemi.

(w. 470-473).

Słowa dziewicy łączą się ze słowami Guślarza o rzucaniu potraw w róg kaplicy, bowiem w całym tym rytuale nie chodzi o faktyczny akt spożywania - przecież przybyłe na ucztę duchy/dusze nie konsumowały ofiarowanych im potraw naprawdę - lecz o intencję, z jaką jadło jest ofiarowywane. Intencja bowiem pochodzi od konkretnego człowieka, tego, który nią obdarza i jest niczym więcej, jak jego energią. To ona stanowi treść pokarmu zmarłych, 
a pojawia się w magicznym czasie misterium: między gestem wzięcia do ręki pokarmu a rzuceniem go w róg kaplicy. Wtedy duch ma szansę na pożywienie się, a tym samym zbawienie lub choćby częściowe odpuszczenie grzechów.

Mickiewicz, jak zaznaczył we wstępie do Dziadów, wzrastał, słuchając bajek, powieści i pieśni, które pobudzały jego wyobraźnię. Baśnie bowiem zawierają strukturę mityczną. Ta zaś odnosi się do rytuałów i obrzędów, w których występują pokarmy o zaświatowym charakterze: jedne przynoszą śmierć, inne pomagają ułaskawić demony czy ożywić zmarłych.

Jedną z najsłynniejszych baśni rosyjskiego folkloru jest opowieść o Wasylisie Pięknolicej znanej także pod tytułem O mądrej Wasylisie. Już na wstępie opowieści czytamy:

Był sobie w pewnym królestwie kupiec. Przeżył ze swoją żoną dwanaście lat i urodziła im się jedyna tylko córka, Wasylisa Pięknolica. Odumarła matka Wasylisę, kiedy dziewczynka miała osiem lat. Przed śmiercią kupcowa zawołała do siebie córkę, wyjęła spod kołdry lalkę i dała ją Wasylisie mówiąc:

- Posłuchaj, córeczko, zawsze pamiętaj moje ostatnie słowo i bądź mi posłuszna. Umieram i wraz z moim matczynym błogosławieństwem pozostawiam ci tę oto lalkę. Trzymaj ją zawsze przy sobie i nikomu nie pokazuj, a jeżeli spotka cię jakieś nieszczęście, daj lalce coś do zjedzenia i poproś ją o radę. Lalka zje i powie ci, jak zaradzić nieszczęściu.

Matka pocałowała córeczkę i niebawem zmarła ${ }^{14}$.

Cytowany fragment ukazuje rytuał błogosławieństwa, jaki udziela matka córce podczas obrzędu inicjacyjnego dziewcząt zwanego zaplecinami. Błogosławieństwo - dobre słowo, które miało moc ochrony przed wszelkim złem i nieszczęściem - zostaje w baśni utożsamione z lalką. Umierająca matka ma świadomość, że nie będzie mogła chronić córki ani wspierać jej swoją radą, dlatego ofiarowuje jej strażniczkę w postaci lalki. Co istotne, przykazuje ona córce, by zawsze trzymała/nosiła lalkę przy sobie, zapewne blisko ciała, tak by lalka „nasiąknęła” energią dziewczynki i pozostawała z nią w stałym duchowym kontakcie. Ponadto, zgodnie z nakazem matki, nikt nie może lalki zo-

14 Wasylisa Pięknolica, [w:] Piórko Finista Jasnego, Cud-Sokoła. Rosyjskie baśnie ludowe, przeł. M. Dolińska, Moskwa 1990, s. 27. 
baczyć, co wiąże się z symboliką urocznych oczu, czyli takich, które poprzez swój złowrogi charakter mogłyby odebrać lalce jej moc.

Ofiarowana przez matkę lalka należy do obrzędowych lalek słowiańskich, których podstawową funkcją była ochrona, spełnianie życzeń, przynoszenie szczęścia i obfitości, dlatego właśnie pełniły funkcję duchowo-energetycznych amuletów. W zależności od swojego przeznaczenia lalki te miały różny wygląd oraz nazwy. I tak na przykład lalki spełniające życzenia to Żadanice, pilnujące domu to Ziarnuszki, towarzyszące wyprawie to Podróżniczki, a przygotowywane na wesele to Nierozłączki. W procesie motania lalki najważniejsza była intencja tego, który ją tworzył, zaś sama lalka była efektem jego emocji oraz życzeń. Jak możemy wywnioskować, lalkę dla Wasylisy zrobiła jej mama, dlatego miała ją chronić i we wszystkim jej pomagać.

$\mathrm{Z}$ tekstu nie wynika czy lalka, zgodne z zasadami rytualnego motania, została wykonana przez matkę z jej własnych ubrań, które posiadały funkcję ochronną, czy też miała na sobie jakieś inne ubranie, wiadomo natomiast, że w razie potrzeby należało najpierw lalkę nakarmić, a dopiero potem poprosić o pomoc. Do wymienionych lalek należy dodać jeszcze jedną, a mianowicie laleczkę o długim warkoczu, nazywaną Lalką na szczęście. Jest ona zupełnie maleńka, dlatego bez przeszkód można ją trzymać przy sobie cały czas; pełni funkcję amuletu, jest także opiekunką i obrońcą domowego paleniska. I tę właśnie lalkę, sądząc z opisu, otrzymała Wasylisa od matki, która nie powiedziała jednak, czym należy lalkę karmić.

Z tekstu baśni wiadomo, że będąc jeszcze w domu macochy, dziewczyna stawiała przed lalką ,przygotowaną dla niej wieczerzę”, zaś w chacie Baby Jagi częstowała ją resztkami ze stołu wiedźmy. Na owe ochłapy składało się kilka łyżek kapuśniaku, skibka chleba, kawałeczek prosięcia oraz kwas chlebowy, miód pitny, piwo i wino. Wszystkie te potrawy, którymi Wasylisa karmiła lalkę, należą do jadła, jakim goszczono uczestników styp pogrzebowych oraz samego zmarłego. Kapusta jest bowiem składnikiem wielu potraw wigilijnych czy uczt zmarłych, dodatkowo na jej zaświatowy charakter wskazuje fakt, że wedle wierzeń rodziły się w niej dzieci. Chleb stanowi podstawowy posiłek duchów, podobnie jak związany z nim symbolicznie kwas chlebowy, z kolei piwo było napojem władców i stosowano je w rytuałach przejścia w dorosłość ${ }^{15}$ (a wszak 


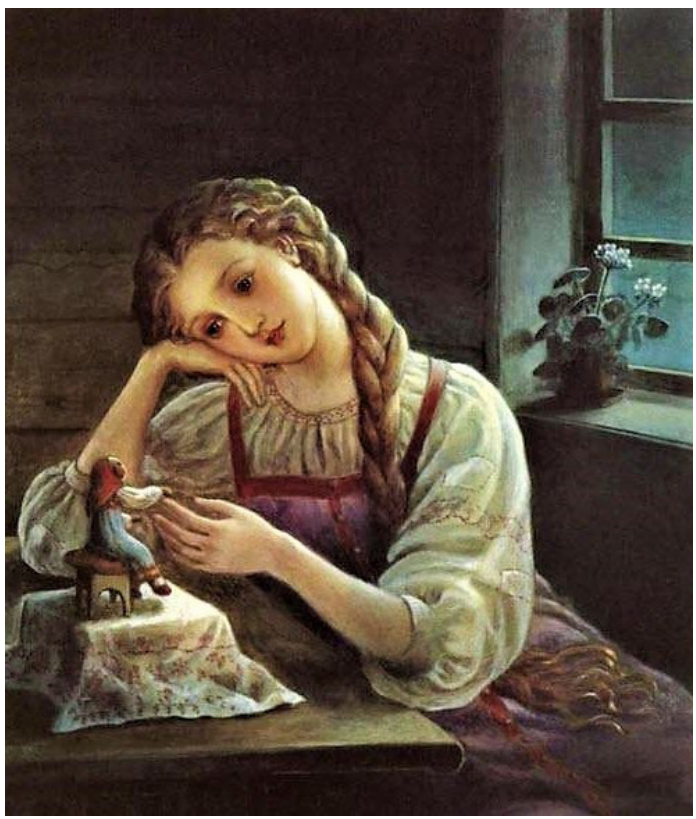

Autor: Kinuko Y. Craft

Wasylisa w chacie jędzy przechodzi inicjację i zyskuje głęboką świadomość samej siebie jako człowieka i jako kobiety), wino uważano za napój zmarłych oraz symbol krwi ${ }^{16}$, zaś miód traktowany był jako substancja zaświatowa, gdyż zbierano go poza granicami ludzkiej bytności, posiadał ponadto znakomite właściwości konserwujące, które łączyły go ze śmiercią ${ }^{17}$. Kiedy więc lalka ,zjadła” ofiarowany pokarm, jej oczy rozbłyskiwały niczym dwie świeczki i albo udzielała rad, albo wykonywała za dziewczynę wszystkie wyznaczone przez jędze polecenia. Najważniejszym stawało się zdobycie ognia, co w przypadku lalki - strażniczki domowego paleniska - nie było kwestią przypadku.

Ofiarą-mediatorem w kontaktach ze zmarłymi oraz istotami ze sfery zaświatowej był chleb, toteż nie dziwi wcale, że w takiej właśnie roli objawia się on w baśni Braci Grimm zatytułowanej Żywa woda. Opowiada ona o królu, który zachorował i tylko żywa woda mogła mu przywrócić zdrowie. Starszy i młodszy syn, którzy wyruszyli na poszukiwanie cudownego źródła, prze-

\footnotetext{
16 H. Biedermann, Leksykon symboli, przeł. J. Rubinowicz, Warszawa 2003, s. 407.

17 P. Kowalski, dz. cyt., s. 319.
} 
padli bez wieści, przyszła więc kolej na najmłodszego z braci. Ten prawidłowo odpowiedział na pytanie napotkanego karła, za co został przez niego obdarowany nie tylko wskazówką, jak dotrzeć do wody życia, lecz także darami, które umożliwią mu jej zdobycie. Do tych należy żelazna rózga oraz dwa bochenki chleba. Żelazo łączy się ze sferą śmierci, a także zaświatami i dlatego używane jest jako oręże do walki z demonami ${ }^{18}$, rózga, która jest pochodną magicznej różdżki, służy jako klucz do otwarcia bramy zaświatowego królestwa - miejsca, skąd wytryska życiodajne źródło. Na jego straży znajdują się dwa lwy, to one właśnie mają zostać przez bohatera nakarmione chlebem. Dzieje się tak, ponieważ lwy poprzez swój związek z krwią są istotami demonicznymi, należącymi do sfery śmierci, z tej właśnie przyczyny pełnią funkcje strażników cmentarzy, przeklętych pustkowi lub przestrzeni związanych z magicznymi przedmiotami. Dlatego więc chleb, który z racji swych mediumicznych właściwości służy do podtrzymywania komunikacji z sacrum: z bogami, duszami zmarłych, został w baśni użyty do ułaskawiania demonów. Ale nie tylko ich, bowiem bardzo często natykamy się na teksty, w których bóstwa ucztują, jedząc chleb.

Zgodnie z tradycją i przyjętym zwyczajem świętujemy sylwester znany wcześniej i obchodzony jako ucztę wróżek, trzech bogiń losu, zwanych w zależności od podań i przekazów: Mojrami, Rodzanicami czy Narecznicami. W wieczór biesiady, który przypada na ostatni dzień roku, ustawiano na stole, nierzadko osobnym, wino oraz chleb, którymi boginie miały się posilić. O świcie 1 stycznia wokół stołu gromadzili się domownicy z gospodarzem na czele, który kroił chleb, maczał go winie i częstował każdego domownika, by ten mógł uczestniczyć w komunii z bóstwem ${ }^{19}$. Brak pokarmu dla wróżek mógł spowodować ich gniew, a na rodzinę sprowadzić klęskę nieurodzaju. Echo tego starego zwyczaju pobrzmiewa w micie o wojnie trojańskiej, kiedy to na weselne gody Tetydy z Pelopsem nie zaproszono do stołu bogini Eris. Jej gniew i chęć zemsty sprawiły, że między ucztującymi pojawiło się złote jabłko, symbol niezgody, zwiastun wyniszczającej wojny. Podobnie rzecz ma się w baśni o Śpiącej królewnie, kiedy to na chrzest królewskiego dziecka nie zaproszono jednej z wróżek. W ten sposób doszło do złamania odwiecznego

18 W. Kopaliński, dz. cyt., s. 504.

19 P. Walter, Mitologia chrześcijańska, przeł. E. Burska, Warszawa 2006, s. 66-68. 
zwyczaju, wedle którego boginie zapraszano na uczty towarzyszące ważnym momentom życia, a takim bez wątpienia były narodziny królewny.

Obok chleba, wina i wody pokarmem, który posiada zaświatowy charakter, jest samo ciało. Bardzo często w baśniach potwór pożera młodzieńców czy dziewicę, zdarza się też, że to krewni zjadają zmarłe dziecko. W baśni Braci Grimm pod tytułem Krzak jałowca z ciała zamordowanego chłopca macocha ugotowała potrawkę, którą ze smakiem zjadł jej mąż, ojciec malca. O straszliwej zbrodni wyśpiewywał zaś śliczny ptaszek, przysiadając na gałązkach jałowca:

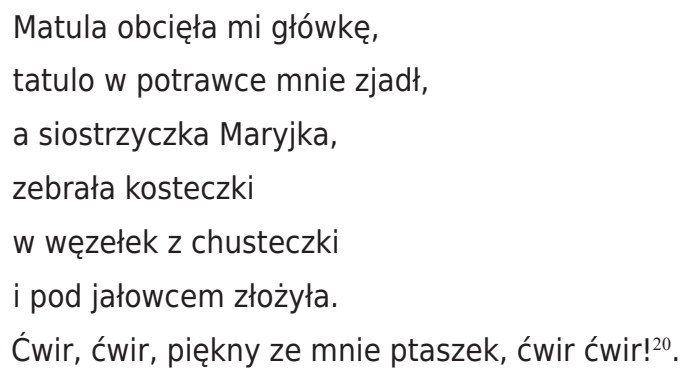

Historia o zjadaniu własnych dzieci pojawiła się już w mitologii, gdzie Kronos zazdrosny o swą władzę połykał kolejno Demeter, Hadesa, Posejdona i Hestię, czy w tragicznej historii rodu Atrydów, kiedy to Atreus podał podczas uczty swemu bratu pieczeń z jego synów. W tych wszystkich przykładach odnajdujemy starodawny rytuał śmierci Dębowego Króla, Oblubieńca Wielkiej Bogini. Obrzęd ten opierał się na magicznym akcie przeistoczenia chleba w ciało, który wedle zasady transsubstancjacji mówił, że duch zboża przybierał ludzką postać i jako taki był mordowany (jego ciało rąbano na kawałki, krzyżowano lub palono), a następnie uroczyście zjadany jako sakrament. W tym celu z mąki rożnych ziaren wypiekano małe bochenki o ludzkim kształcie, które spożywano, popijając wywarem z jęczmienia ze świętego kielicha ${ }^{21}$.

Odmianę tego motywu spotykamy w baśni Wandy Dobaczewskiej Złota studzienka. Główną bohaterką opowieści jest dziewczyna o imieniu Mary-

20 Krzak jałowca, [w:] Baśnie Braci Grimm, t. I, przeł. E. Bielicka i M. Tarnowski, Warszawa 1986, s. 225.

21 J. G. Frazer, Zlota gałaź, przeł. H. Krzeczkowski, Warszawa 2002, s. 350-356. 
sia, która po osieroceniu jej przez matkę pozostaje na łasce złej gospodyni. Jedyną pocieszycielką dziewczyny jest łaciata krowa, która pomaga jej wykonywać ciężkie prace. Po jakimś czasie gospodyni wszystkiego się domyśla i postanawia zabić zwierzę. Wtedy krowa przykazuje sierotce, by z jej ciała zostawiła sobie jedynie rogi, które powinna zakopać pod płotem, w miejscu, gdzie w południe świeci słońce. Zrozpaczona dziewczyna postępuje zgodnie z wskazówkami Łaciatej: zakrada się w nocy do ogrodu i przy świetle księżyca, ucałowawszy z czułością rogi, składa je do ciemnej ziemi niczym do grobu. Wtedy też dochodzi do magicznego aktu transformacji, który przebiegał w następujący sposób:

Rankiem spadł deszcz ciepły, obfity, potem słońce wyjrzało zza chmur i zalało cały ogród gorącymi promieniami. Przez trzy dni na ziemię deszcz padał i słońce świeciło, a czwartego dnia w samo południe, dziw się stał nad dziwy. Z czarnej ziemi pod potem, spomiędzy pokrzyw i jaskółczego ziela, wychyliła się złota studzienka ${ }^{22}$.

Opisywany na kartach baśni rytuał dokonuje się w nocy, która związana jest z zaświatami, ponadto jest porą, która łączy się z kiełkowaniem roślin, wszelkim przekształceniem, a także przejściem jednego stanu w drugi, podobnie jak w obrzędzie wesela. Dziewczyna ucałowała rogi ${ }^{23}$, gdyż pocałunek wiąże się z oddechem, powietrzem, a przez to z życiem. Przemiana rozpoczyna się rankiem lub, jakbyśmy mogli też powiedzieć, o świcie. To część dnia, która posiada moc przepłaszania śmierci, demonów oraz wszelkich nieszczęść. Deszcz ma moc zapładniania, słońce swym światłem (ciepłym) daje życie. Całe przeistoczenie trwa trzy dni, gdyż liczba ta oznacza twórczość, wzrost oraz narodziny ${ }^{24}$, a dochodzi do niego w południe, ponieważ o tej porze, w środku dnia, ma miejsce chwilowy bezruch, zatrzymanie, podczas którego

22 W. Dobaczewska, Złota studzienka, [w:] U złotego źródła. Baśnie polskie, wybór S. Wortman, Warszawa 1989, s. 21.

23 Na temat solarnej symboliki rogów zob. M. Lurker, Słownik obrazów i symboli biblijnych, przeł. K. Romaniuk, Poznań 1989.

24 W. Kopaliński, dz. cyt., s. 433. 
możliwe staje się obcowanie z sacrum i zaświatami ${ }^{25}$. Wtedy też otwierają się bramy między światem żywych a umarłych i pojawiają się rozmaite istoty (np. Południca), zaś w analizowanej baśni ukazuje się złota studzienka. Wynurza się ona między jaskółczym zielem, które posiada właściwości magiczne, takie jak obdarzanie zdrowiem oraz siłą, a pokrzywą, której podstawowa funkcja polega na zapewnieniu ochrony przed demonami ${ }^{26}$. Wszystko to razem wzięte oznacza, że ciało krowy uległo pod ziemią (dla której też było pokarmem) transformacji w złotą studnię, która stanowi przejście w zaświaty, stąd nie dziwi wcale, że w baśniowej złotej studzience zamiast wody znajdowało się wino.

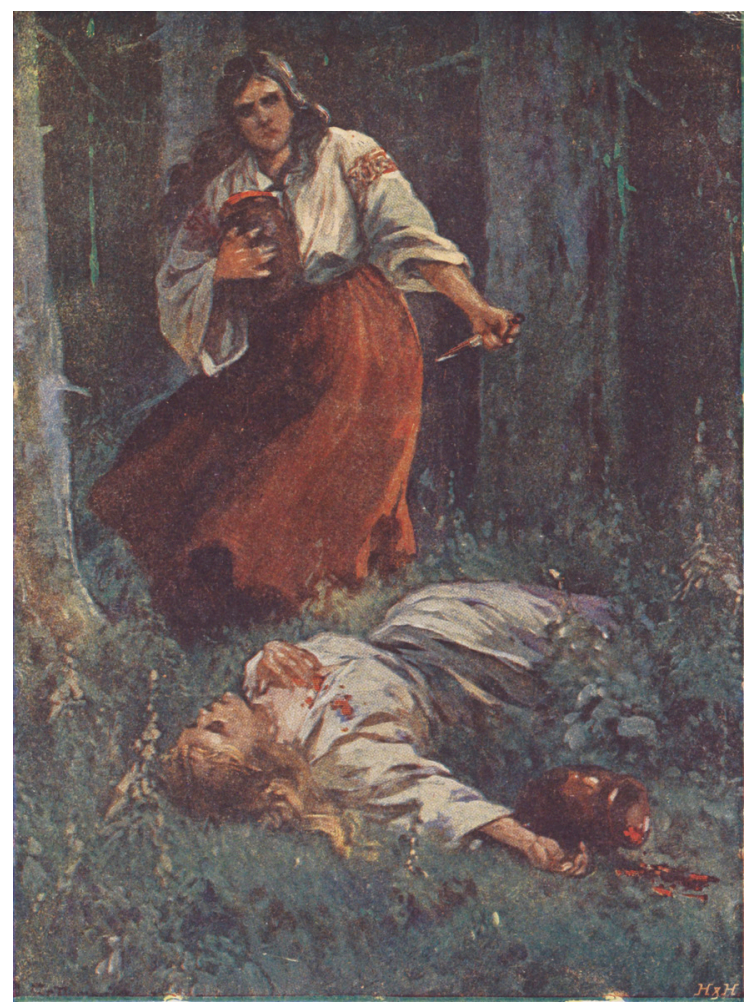

Autor: Adam Setkowicz

25 A. Brzozowska-Krajka, Symbolika dobowego cyklu powszedniego w polskim folklorze tradycyjnym, Lublin 1994, s. 141-163.

26 P. Kowalski, dz. cyt., s. 459. 
Obok wspomnianych już pokarmów dla zmarłych, takich jak soczewica, bób czy chleb, szczególne miejsce zajmują owoce. Symbolizują one grzech, stanowią siedzibę duszy, ale też posiadają silne seksualne i zmysłowe konotacje, które pozostają oczywiście w związku ze śmiercią ${ }^{27}$. Najsłynniejszym tego typu pokarmem jest jabłko. Ono to poprzez swój kształt, zwłaszcza po przekrojeniu, nasuwa erotyczne skojarzenia, toteż jabłka spożywali nowożeńcy przed udaniem się do łożnicy, zaś Śnieżka po zjedzeniu jabłka złożona została do szklanej trumny ${ }^{28}$. Podobnie rzecz ma się z malinami, które oznaczają dobroć, lecz ze względu na swój kształt kojarzone są z kobiecym sutkiem $^{29}$. Nieprzypadkowo więc Kirkor prosi, by córki wdowy nazbierały malin, bo tę, której się ta sztuka uda, uczyni władczynią i wprowadzi do swej łożnicy. W wersji Kazimierza Wójcickiego zatytułowanej Piszczałka zabójczym owocem okazały się jagody ${ }^{30}$. Co istotne zarówno kolor malin, jak i jagód, przywodzi na myśl skojarzenie z krwią. Jednak w przypadku jagód plamy są trudniejsze do wywabienia, co istotne na dłoniach utrzymują się bardzo długo, niczym znak popełnionej zbrodni, a tym samym kontaktu z zaświatami. Dlatego właśnie Balladyna, na której czole znajdowało się ukryte pod wstążką Kainowe znamię - krwawa plama, jako jedyna spośród uczestników uczty nie tylko słyszała, lecz także widziała zmarłą siostrę, a do tego czuła woń malin.

Omówione w niniejszym tekście pokarmy o zaświatowym charakterze nie wyczerpują tematu potraw, jakie ofiarowywano zmarłym, uświadamiają jednak, że każdy byt potrzebuje energii. Dzięki niej możliwe jest (współ)istnenie świata żywych i umarłych, a przez to fakt, że jedni nie mogą obyć się bez drugich.

27 Leksykon symboli, Herder, dz. cyt., s. 210; Á. P. Chenel, A. S. Simarro, dz. cyt., s. 174.

28 Nasuwa się tu oczywiście skojarzenie z mitem o Demeter i Korze, która w Hadesie zakosztowała kilku pestek granatu. Te nie uczyniły jej co prawda martwą, lecz już na zawsze związały z Krainą Śmierci.

29 Leksykon symboli, Herder, dz. cyt., s. 162.

30 K. Wójcicki, Piszczałka, [w:] Baśnie polskie, wyb. i oprac. T. Jodełka-Burzecki, Warszawa 1972, s. 27. 
Iwona E. Rusek, „Jedz, laleczko...", czyli o zaświatowym charakterze niektórych potraw

\section{Bibliografia}

Baśnie Braci Grimm, t. I, przeł. E. Bielicka i M. Tarnowski, Warszawa 1986.

Biedermann H., Leksykon symboli, przeł. J. Rubinowicz, Warszawa 2003.

Biegeleisen H., Śmierć w obrzędach i zwyczajach ludu polskiego, Sandomierz 2017. Brzozowska-Krajka A., Symbolika dobowego cyklu powszedniego w polskim folklorze tradycyjnym, Lublin 1994.

Charytoniuk-Michiej G., Obrzęd Dziadów w dokumentach i w cyklu Mickiewicza, Warszawa 2011.

Chenel Álvaro P., Simarro A. S., Słownik symboli, przeł. M. Boberska, Warszawa 2008.

Dobaczewska W., Złota studzienka, [w:] U złotego źródła. Baśnie polskie, wybór S. Wortman, Warszawa 1989.

Frazer J. G., Złota Gałąź, przeł. H. Krzeczkowski, Warszawa 2002.

Fischer A., Zwyczaje pogrzebowe ludu polskiego, Lwów 1921.

Kopaliński W., Słownik symboli, Warszawa 1990.

Kowalski P., Kultura magiczna. Omen, przesąd, znacznie, Warszawa 2007.

Mickiewicz A., Dziady, Warszawa 1995.

Ogrodowska B., Polskie zwyczaje i obrzędy doroczne, Warszawa 2012.

Piórko Finista Jasnego, Cud-Sokoła, Rosyjskie baśnie ludowe, przeł. M. Dolińska, Moskwa 1990.

Tresidder J., Słownik symboli, przeł. B. Stokłosa, Warszawa 2005.

Walter P., Mitologia chrześcijańska, przekł. E. Burska, Warszawa 2006.

Wawrzeniuk J., Jak wyglądały słowiańskie "mosty" w zaświaty? - Spojrzenie archeologiczne, [w:] Za miedzę, za morze, w zaświaty... Kulturowe wymiary podróżowania, red. W. Olszewski, V. Wróblewska, Wrocław 2012.

Wójcicki K., Piszczałka, [w:] Baśnie polskie, wybór T. Jodełka-Burzecki, Warszawa 1972. 